\title{
Breeding for resistance to bymoviruses in Poaceae with special consideration for the barley yellow mosaic virus complex
}

\author{
W Friedt *, F Ordon \\ Institute of Crop Science and Plant Breeding, Justus-Liebig-University, Ludwigstr 23, D-35390 Giessen, Germany
}

(Received 20 May 1995; accepted 4 July 1995)

\begin{abstract}
Summary - Bymoviruses, ie BaYMV, BaMMV, WYMV, WSSMV, OMV and RNMV, cause serious damages to their host-plants, resulting in high yield losses in susceptible crops. Due to their transmission by the soil-borne fungus Polymyxa graminis, chemical measures against these diseases are neither efficient nor acceptable for economical and ecological reasons. Therefore, breeding resistant varieties is an important aim for plant breeding. Besides classical breeding methods completed by the production of $\mathrm{DH}$-lines and marker-facilitated selection procedures, recombinant DNA-techniques may give way to new strategies in breeding for resistance to bymovirus in Poaceae in the near future.
\end{abstract}

bymoviruses / Poaecae / resistance / barley yellow mosaic / breeding / recombinant DNA-techniques

Résumé - Sélection pour la résistance aux bymovirus chez les poacées en considérant particulièrement le complexe des virus des mosaïques de l'orge. Les bymovirus : BaYMV, BaMMV, WYMV, WSSMV, OMV, RNMV causent de sérieux dégâts à leurs plantes hôtes, entraînant d'importantes pertes de rendement chez les cultures sensibles. À cause de leur transmission par le champignon du sol Polymyxa graminis, les traitements chimiques sont soit inefficaces, soit inacceptables pour des raisons économiques ou écologiques. Ainsi, la création des variétés résistantes est un objectif majeur de sélection. À côté des schémas classiques d'amélioration des plantes, complétés par les techniques de production de lignées haploïdes doublées par un marquage moléculaire, les méthodes de recombinaison de I'ADN pourront sans doute donner naissance dans un avenir proche à de nouvelles stratégies de sélection pour la résistance contre les bymovirus des poacées.

bymovirus / poacées / résistance / mosaïque de l'orge / sélection / ADN recombinant

\section{INTRODUCTION}

The bymovirus-group founded by Usugi et al (1989) consists of viruses with a bipartite genome which are mostly serologically related and transmitted by the soil-borne fungus
Polymyxa graminis, ie barley yellow mosaic virus (BaYMV), barley mild mosaic virus (BaMMV), wheat yellow mosaic virus (WYMV), wheat spindle streak mosaic virus (WSSMV), oat mosaic virus (OMV), and rice necrosis mosaic virus (RNMV). Because WYMV and WSSMV show

* Correspondence and reprints 
very similar features they may be considered as strains of the same virus (Usugi and Saito, 1979; Usugi et al, 1989), while BaMMV and BaYMV are considered as distinct viruses (Huth and Adams, 1990). The host range of bymoviruses is quite limited, although BaMMV has been mechanically transmitted to triticale (Triticosecale Wittmack, Kegler et al, 1985), rye (Ordon et al, 1992) and Triticum turgidum (Proeseler, 1993). Despite of the limited host range, these viruses are infectious to crops of major agronomic importance, ie wheat, barley, oats and rice (table I). Depending on the climatic conditions they cause high grain yield losses in susceptible crops, eg, OMV in oats $66-78 \%$ (Catherall and Boulton, 1979) and up to $100 \%$ (Coffmann et al, 1962), WSSMV in wheat 3-87\% (Miller et al, 1992; Cunfer et al, 1988 ) or BaYMV/BaMMV in barley $50-100 \%$ (Huth, 1984; Friedt et al, 1990). Due to the transmission by the soil-borne fungus $P$ graminis chemical measures against the diseases are neither efficient nor acceptable for economical and ecological reasons. Therefore, breeding for resistance is the only way to prevent yield reductions in infested growing areas. Since RNMV is limited to Japan and India (Gosh, 1981), the following considerations on resistance breeding will focus on the viruses present in Europe with special emphasis on the type member of bymoviruses, barley yellow mosaic virus.

\section{BREEDING}

\section{Via sexual recombination}

A prerequisite for resistance breeding is the identification of resistant sources and a detailed knowledge of the genetics of resistance. Concerning OMV extensive screening programmes were carried out identifying resistant varieties and lines in Avena sativa, $A$ byzantina, the diploid species $A$ strigosa (Graham et al, 1969; Catherall and Valentine, 1987) as well as in $A$ sterilis, the hexaploid progenitor of cultivated oats (Uhr and Murphy, 1992). However, in contrast to the yellow mosaic inducing viruses of barley, resistance to OMV is not complete, ie even highly resistant plants may be infected but display only slight symptoms and do not suffer from the disease like susceptible plants. Genetic analysis revealed that resistance/tolerance to OMV is quantitatively inherited (table I) and the degree of heritability was estimated to be in the range of 0.59-0.88 (ie 59-88\%; Byrd et al, 1971; Uhr and Murphy, 1992).

In contrast to oats and OMV, resistance of wheat to WSSMV is complete and several sources of resistance were identified in $T$ aestivum (Wiese et al, 1974; Jackson et al, 1976;

Table I. Members of the bymovirus group, their hosts, occurrence, sources of resistance, genetics of resistance and status of breeding.

\begin{tabular}{|c|c|c|c|c|c|}
\hline Virus & $\begin{array}{l}\text { Crop } \\
\text { species }\end{array}$ & $\begin{array}{l}\text { Occurrence } \\
\text { (Country) }\end{array}$ & $\begin{array}{l}\text { Sources of } \\
\text { resistance }\end{array}$ & Genetics of resistance & Breeding \\
\hline $\begin{array}{l}\text { BaYMV } \\
\text { BaMMV }\end{array}$ & Barley & $\begin{array}{l}\text { France, UK, Germany, } \\
\text { Belgium, The Netherlands, } \\
\text { Italy, Ukraine, } \\
\text { Japan, China }\end{array}$ & $\begin{array}{l}\text { H vulgare } \\
\text { H spontaneum } \\
\text { H bulbosum }\end{array}$ & $\begin{array}{l}\text { Simply inherited dominant and recessive genes } \\
n\end{array}$ & Resistant cultivars available \\
\hline OMV & Oats & $\begin{array}{l}\text { UK, Japan, } \\
\text { New Zealand, USA }\end{array}$ & $\begin{array}{l}\text { A sativa } \\
\text { A byzantina } \\
\text { A strigosa } \\
\text { A sterilis }\end{array}$ & Quantitative, $\mathrm{H}=0.7-0.8$ & Resistant cultivars available \\
\hline $\begin{array}{l}\text { WSSMV } \\
\text { WYMV }\end{array}$ & Wheat & $\begin{array}{l}\text { Canada, USA, } \\
\text { France, Germany }\end{array}$ & $\begin{array}{l}T \text { aestivum } \\
T \text { durum } \\
T \text { monococcum } \\
T \text { tauschii }\end{array}$ & $\begin{array}{l}\text { Two loci, additive dominant } \\
m\end{array}$ & Resistant cultivars available \\
\hline RNMV a & Rice & Japan, India & $\begin{array}{l}\text { O sativa spp } \\
\text { Japonica, Indic }\end{array}$ & & \\
\hline
\end{tabular}


Haufler and Fulbright, 1986) and $T$ durum (Rubies-Autonell and Vallega, 1990). In the USA 2 varieties were recently released carrying resistance genes derived from $T$ tauschii (Cox et al, 1994). Resistance of $T$ aestivum was reported to be inherited by a single dominant gene (Wiese et al, 1974) or in an additive dominant manner (table I) with 3 alleles at the A-locus and 2 alleles at the B-locus, respectively (van Koevering et al, 1987).

The most extensive information on resistance and genetics of resistance is available for the yellow mosaic inducing viruses of barley. Extensive screening programmes carried out in Japan (eg, Kawada, 1991) and Germany (eg. Friedt et al, 1990; Huth, 1991; Ordon et al, 1993) revealed that resistance is present in many varieties and can also be found in the ancestor of cultivated barley, Hordeum spontaneum (Erdogan et al, 1994). In genetic analyses carried out on the resistance of barley against BaMMV it turned out that different resistance genes are present within the gene pool of barley (Götz and Friedt, 1993; Ordon and Friedt, 1993; table I). These genes may even act in a specific way to the different virus of the barley yellow mosaic virus complex (Ordon et al, 1992b). Furthermore, genetic analysis revealed that resistance to the German isolate of BaMMV is inherited recessively in any case (Ordon and Friedt, 1993). However, since all these resistance genes encode for complete (qualitative) resistance the widespread use of only one or very few of these genes may be the reason for the selection of new virus-strains. In Japan 6 strains of BaYMV and 2 of BaMMV have already been described (Kashiwazaki et al, 1990b). In Europe the extensive use of the resistance gene $y m 4$ may be the major reason for the selection of the new strain, BaYMV-2 (Huth, 1991).

Since resistance to bymoviruses is only 1 breeding goal among many others, genes for virus resistance have to be combined with numerous other genes necessary for excellent agronomic performance. This 'combination breeding' usually requires several breeding steps. The major hosts of bymoviruses, ie barley, oats, rice and wheat, are self-pollinating species ('inbreeders'). Cultivars of such species are usually inbred lines and the breeding methods are often summarized as 'line breeding' methods. Specific breeding methods are, for example, the pedigree method, the bulk-population breeding method, and modifications of them.

As BaMMV-resistance is inherited by a single recessive gene, selection may be carried out as early as in the $F_{2}$ generation efficiently. In contrast, selection for more complex inherited WSSMV-resistance and especially OMV-resistance will be more efficient in later generations. Donors of resistance, eg, primitive forms or landraces, are in general of inferior agronomic performance; this is at least the case for resistance to the yellow mosaic inducing viruses of barley (Ordon and Friedt, 1994). Therefore, backcrossing programmes have to be applied in order to combine virus resistance with sufficient agronomic performance.

The breeding methods mentioned above are time consuming and it must be taken into account that uniformly infested fields or highly efficient mechanical inoculation methods must be available for an effective selection of single $F_{2^{-}}$ plants. Therefore, the introgression of resistance genes into adapted varieties may be abridged and selection in early generations becomes much easier by the use of doubled haploid (DH) lines (Foroughi-Wehr and Wenzel, 1990). Especially in breeding for quantitatively inherited type of resistance, like that of oats against OMV, $\mathrm{DH}$-lines would be highly useful for an efficient recurrent selection procedure in order to accumulate resistance genes to this virus in breeding populations. Furthermore, the use of RFLP and RPAD markers offers the opportunity of an efficient marker-based selection for virus resistance today. The BaYMV/BaMMV-resistance gene ym4 has been shown to be closely linked to an RFLP marker (Graner and Bauer, 1993) and to an RAPD marker (Ordon et al, 1995), respectively. Both facilitate marker-based selection avoiding the need of uniformly infested fields or mechanical inoculation procedures. Furthermore, the identification of RAPD or RFLP markers for different resistance genes offers the opportunity to combine these genes in 1 variety efficiently, ie the 'pyramiding' of resistance genes.

\section{By recombinant DNA-techniques}

The conventional breeding methods mentioned above - including the use of $\mathrm{DH}$-lines and marker-assisted selection - are the most commonly used methods in practical plant breeding today. However, recombinant DNA-techniques may offer new strategies in breeding for resistance to bymoviruses in the future. Detailed RFLP-maps of barley (eg, Graner et al, 1994), wheat (Liu and Tsunewaki, 1991) and rice (Tanksley et al, 1992) are available. Starting from these maps, corre- 
sponding resistance genes may be isolated by map-based cloning strategies. The effectiveness of map-based cloning in isolating resistance genes has already been proven in Arabidopsis thaliana (Bent et al, 1994) and tomato (Martin et al, 1993). Different resistance genes against BaMMV were already integrated into the RFLPmap of barley and, notably, the $y m 4$ locus has been well characterized by RFLP (Graner and Bauer, 1993), RAPD (Ordon et al, 1995), and isozyme markers (Le Gouis et al, 1995) so that map-based cloning strategies may be applied to this locus in the near future. However, regeneration of protoplasts and genetic transformation of Poaecae are still problematic, although evident progress has been made recently. Nevertheless, besides a deeper knowledge of resistance, the direct transfer of isolated resistance genes into adapted cultivars would avoid the segregation of negative agronomic traits, which otherwise always takes place in breeding by sexual recombination.

The strategies mentioned are based on resistance genes derived from plant species. However, resistance to bymoviruses may also be engineered by using the corresponding genetic information of the viruses. The RNA-sequences of German and Japanese isolates of BaYMV and BaMMV - at least of the sequences encoding for the coat protein - are known (Kashiwazaki et al, 1989, 1990a, 1991, 1992; Davidson et al, 1991; Peerenboom et al, 1992; Bendiek et al, 1993; Schlichter et al, 1993; Foulds et al, 1993). Similar information is available for WSSMV (Sohn et al, 1994). Therefore, coat protein mediated resistance or resistance derived from anti-sense constructs - as already known from many dicot species (Steinbiss, 1993) - may be available in the future, too. However, the effectiveness of this strategy also requires efficient transformation and regeneration systems for Poaceae.

Traditional breeding schemes will definitely be supplemented by genetic transformation systems in the future. However, it must always be taken into account that most of the strategies in breeding for resistance to bymoviruses are dealing with simply inherited qualitative resistances, which may be easily overcome by new virus strains. An exception is OMV, where the quantitative resistance of $\mathrm{cv}$ 'Fulghum' has been working for more than 40 years (Uhr and Murphy, 1992). Therefore, despite all attempts and success already made, the race between resistance of Poaceae and virulence of bymoviruses is still on.

\section{REFERENCES}

Bendiek J, Davidson AD, Schulze SC, Schell J, Steinbiss HH (1993) Identification and classification of a resistance-breaking strain of barley yellow mosaic virus. Ann Appl Biol 122, 481-491

Bent AF, Kunkel BN, Dahlbeck D et al (1994) RPS2 of Arabidopsis thaliana: a leucine-rich repeat class of plant disease resistance genes. Science 265, 18561860

Byrd BW, Graham D, Byrd WP (1971) Inheritance of tolerance to soil-borne oat mosaic virus in oats. Crop Sci 11, 875-877

Catherall PL, Boulton RE (1969) Reaction of some winter oat cultivars to oat mosaic and oat tubular virus. Plant Pathol 28, 57-60

Catherall PL, Valentine J (1987) Resistance to oat mosaic virus in autumn-sown oats. Ann Appl Biol $111,483-487$

Coffman FA, Hebert TT, Gore UR, Byrd WA (1962) Reactions of winter oats to soil-borne mosaic. Plant Dis Rep 46, 428-440

Cox TS, Sorrells ME, Bergstrom GC et al (1994) Registration of KS92WGRC21 and KS92WGRC22 hard red winter wheat germplasms resistant to wheat spindle streak mosaic virus, wheat soilborne mosaic virus and powdery mildew. Crop Sci 34, 546

Cunfer BM, Demski JW, Bays DC (1988) Reduction in plant development, yield and grain quality associated with wheat spindle streak mosaic virus. Phytopathology 78, 198-204

Davidson A, Pröls M, Schell J, Steinbiss HH (1991) The nucleotide sequence of RNA 2 of barley yellow mosaic virus. J Gen Virol 72, 989-993

Erdogan M, Ordon F, Friedt W (1994) Genetics of resistance of Hordeum spontaneum Koch from Turkey to the barley yellow mosaic virus complex. Barley Genet News/ 23, 41-43

Foroughi-Wehr B, Wenzel G (1990) Recurrent selection alternating with haploid steps - a rapid breeding procedure for combining agronomic traits in inbreeders. Theor App/ Genet 80, 564-568

Foulds IJ, Lea VJ, Sidebottom C et al (1993) Cloning and sequence analysis of the coat protein gene of barley mild mosaic virus. Virus Res $27,79-89$

Friedt W, Ordon F, Götz R (1990) Genetics of resistance to the 'barley yellow mosaic virus complex' and status of breeding. Proc 1st Symp Intern Working Group Plant Viruses with Fungal Vectors, Braunschweig, Germany, August 21-24 1990, 117120

Götz R, Friedt W (1993) Resistance to the barley yellow mosaic virus complex. Differential genotypic reactions and genetics of BaMMV-resistance in barley (Hordeum vulgare L). Plant Breed 111, 125131

Gosh SK (1981) Weed hosts of rice necrosis mosaic virus. Plant Dis 65, 602-603 
Graham D, Byrd WP, Kingsland GC (1969) Sources of tolerance to soil-borne oat mosaic virus from the world oat collection. Crop Sci 9, 321-322

Graner A, Bauer E (1993) RFLP mapping of the $y m 4$ virus resistance gene in barley. Theor Appl Genet 86, 689-693

Graner A, Bauer E, Kellermann A et al (1994) Progress on RFLP-map construction in winter barley. Barley Genet News/ 23, 53-59

Haufler KZ, Fulbright DW (1986) Identification of winter wheat cultivars and experimental lines resistant to wheat spindle streak mosaic virus. Plant Dis 70,31 33

Huth W (1984) Die Gelbmosaikvirose der Gerste in der Bundesrepublik Deutschland - Beobachtungen seit 1978. Nachrichtenbl Dtsch Pflanzenschutzd Braunschweig 36, 49-55

Huth W (1991) Verbreitung der Gelbmosaikviren, BaMMV, BaYMV und BaYMV-2 und Screening von Gerstensorten auf Resistenz gegenüber BaYMV-2. Nachrichtenbl Dtsch Pflanzenschutzd Braunschweig 43, 233-237

Huth W, Adams MJ (1990) Barley yellow mosaic virus (BaYMV) and BaYMV-M: 2 different viruses. Intervirology 31, 38-42

Jackson AO, Bracker CE, Shaner G (1976) Mechanical transmission, varietal reactions and electron microscopy of a disease in Indiana with properties of wheat spindle streak mosaic. Plant Dis Rep 60, 202-206

Kashiwazaki S, Hayano T, Minobe T, Omura T, Hibino $H$, Tsuchizaki T (1989) Nucleotide sequence of the capsid protein gene of barley yellow mosaic virus. $J$ Gen Virol 70, 3015-3023

Kashiwazaki S, Minobe Y, Omura T, Hibino H (1990a) Nucleotide sequence of barley yellow mosaic virus RNA 1: a close evolutionary relationship with potyviruses. J Gen Virol 71, 2781-2790

Kashiwazaki S, Nomura K, Watanabe K et al (1990b) Barley yellow mosaic virus and barley mild mosaic virus: strains and host resistance. Proc 1st Sump Intern Working Group Plant Viruses with Fungal Vectors, Braunschweig, Germany, August 21-24 1990, 105-108

Kashiwazaki S, Minobe $Y$, Hibino H (1991) Nucleotide sequence of barley yellow mosaic virus RNA 2. $J$ Gen Virol 72, 995-999

Kashiwazaki S, Nomura K, Kuroda $\mathrm{H}$ et al (1992) Sequence analysis of the $3^{\prime}$-terminal halves of RNA 1 of 2 strains of barley mild mosaic virus. J Gen Virol 73, 2173-2181

Kawada N (1991) Resistant cultivars and genetic ancestry of the resistant genes to barley yellow mosaic virus in barley (Hordeum vulgare $\mathrm{L}$ ). Bull Kyushu Nat Agric Exp Stn 27, 65-79

Kegler H, Haase D, Proeseler G et al (1985) Zur Virusresistenz bei Triticale. Arch Phytopathol Pflanzensch 21, 247-248

Koevering van $M$, Haufler KZ, Fulbright DW, Isleib TG, Everson EH (1987) Heritability of resistance in win- ter wheat to wheat spindle streak mosaic virus. Phytopathology 77, 742-744

Le Gouis J, Erdogan M, Friedt W, Ordon F (1995) Potential and limitations of isozymes for chromosomal localization of resistance genes against barley mild mosaic virus (BaMMV). Euphytica 82, 25-30

Liu YG, Tsunewaki K (1991) Restriction fragment length polymorphism (RFLP) analysis in wheat. II. Linkage maps of the RFLP sites in common wheat. Jpn J Genet 66, 617-633

Martin GB, Brommonschenkel SH, Chunwongse $\mathrm{J}$ et al (1993) Map-based cloning of a protein kinase gene conferring disease resistance in tomato. Science $262,1432-1436$

Miller NR, Bergstrom GC, Sorells ME (1992) Effect on wheat spindle streak mosaic virus on yield of winter wheat in New York. Phytopathology 82, 852-857

Ordon F, Friedt W (1993) Mode of inheritance and genetic diversity of BaMMV resistance of exotic barley germplasms carrying genes different from ' $y m 4$ '. Theor Appl Genet 86, 229-233

Ordon F, Friedt W (1994) Agronomic traits of exotic barley germplasms resistant to soil-borne mosaicinducing viruses. Genet Resour Crop Evolut 41, 4346

Ordon F, Huth W, Friedt W (1992a) Mechanical transmission of barley mild mosaic virus (BaMMV) to rye (Secale cereale L). J Phytopathol 135, 84-87

Ordon F, Erdogan M, Friedt W (1992b) Genetics of resistance of barley to soil-borne mosaic viruses. In: Reprod Biology and Plant Breeding, Proc XIIIth EUCARPIA Congr, July 6-11, Angers, France. Poster Abstracts, 707-708

Ordon F, Götz R, Friedt W (1993) Genetic stocks resistant to barley yellow mosaic viruses. Barley Genet News 22, 46-50

Ordon F, Bauer E, Dehmer KJ, Graner A, Friedt W (1995) Identification of a RAPD-marker linked to the BaMMV/BaYMV resistance gene $y m 4$. Barley Genet News/ 24, 123-126

Peerenboom E, Pröls M, Schell J, Steinbiss HH, Davidson AD (1992) The complete nucleotide sequence of RNA 1 of a German isolate of barley yellow mosaic and its comparison with a Japanese isolate. J Gen Virol 73, 1303-1308

Proeseler G (1993) Triticum durum Desf a further host of barley mild mosaic virus. J Phytopathol 138, 262264

Rubies-Autonell C, Vallega V (1990) Soil-borne wheat mosaic virus and wheat spindle streak mosaic virus in Italy. Proc 1st Symp Intern. Working Group Plant Viruses with Fungal Vectors, Braunschweig, Germany, August 21-24 1990, 135-138

Schlichter U, Sohn A, Peerenboom E, Schell J, Steinbiss HH (1993) Molecular analysis of the capsid protein gene of a German isolate of barley mild mosaic virus. Plant Cell Rep 12, 237-240

Sohn A, Schenk P, Signore PA, Schmitz G, Schell J, Steinbiss HH (1994) Sequence analysis of the $3^{\prime}$ - 
terminal half of RNA 1 of wheat spindle streak mosaic virus. Arch Virol 135, 279-292

Steinbiss HH (1993) Gentechnik zur Erzeugung von Virusresistenz. In: Resistenz von Kulturpflanzen gegen pflanzenpathogene Viren (H Kegler, $\mathrm{W}$ Friedt, eds), Gustav Fischer Verlag Jena, Stuttgart, Germany, 214-231

Tranksley S, Causse M, Fulton T et al (1992) A high density molecular map of the rice genome. Rice Gen News/9, 111-115

Uhr DV, Murphy JP (1992) Heritability of oat mosaic resistance. Crop Sci 32, 328-331
Usugi T, Saito Y (1976) Purification and serological properties of barley yellow mosaic virus and wheat yellow mosaic virus. Ann Phytopath Soc Jpn 42, 12 20

Usugi T, Kashiwazaki S, Omura T, Tsuchizaki T (1989) Some properties of nucleic acids and coat proteins of soil-borne filamentous viruses. Ann Phytopath Soc Jpn 55, 26-31

Wiese MV, Ravenscroft AV, Everson EH (1974) Incidence of wheat spindle streak mosaic among ten wheat cultivars and its effect on yield. Plant Dis Rep 58, 522-525 